\title{
Caracterización del sistema poroso y de su influencia en el deterioro por cristalización de sales en calizas y dolomías explotadas en Abanto (Zaragoza, España)
}

\section{Characterization of pore system and their influence on decay rates caused by salt weathering on limestones and dolostones quarried in Abanto (Zaragoza, Spain)}

\author{
O. Buj(*), P. L. López(*), J. Gisbert(*)
}

Recepción/Received: 09-XII-2008

Aceptación/Accepted: 06-X-2009

Publicado online/Online publishing: 23-II-2010

\section{RESUMEN}

La piedra natural de Abanto es un material utilizado en obra civil moderna y explotado como roca ornamental en Abanto (Zaragoza). Las variedades caracterizadas son una caliza con textura deposicional y una caliza cristalina. En este trabajo se ha realizado un detallado estudio de su mineralogía, textura, características del sistema poroso, comportamiento hídrico, comportamiento dinámico y de su comportamiento frente a la cristalización de sales. La pérdida en peso en estas rocas es inferior al $0,5 \%$ tras realizar 30 ciclos de cristalización de sales. Esta baja alterabilidad es consecuencia de la configuración del sistema poroso, caracterizado por presentar una baja porosidad abierta y porcentajes elevados de microporosidad con tamaños de radios de acceso de poro preferentemente inferiores a 0,2 $\mu \mathrm{m}$.

Sus características petrográficas y físicas, así como su elevada resistencia frente a la cristalización de sales, les confieren unas buenas cualidades técnicas para su utilización como materiales de usos constructivos.

Palabras clave: caliza, dolomía, deterioro, durabilidad, distribución de tamaño de poro.

\section{SUMMARY}

The Abanto natural stone is a rock used in modern constructions and currently quarried as an ornamental rock in Abanto, Zaragoza. The varieties described here are a limestone with depositional texture and a crystalline limestone. In this work we have carried out a detailed study of the mineralogy, texture, hydric behaviour, pore system characteristics, dynamic behaviour and behaviour against the effects of salt crystallisation. After 30 cycles of salts crystallization, the weight loss in these rocks is lower than $0.5 \%$. This low weathering is a consequence of the configuration of their pore system, characterised by a low open porosity and high percentages of microporosity with pore-throat sizes on average of less than a $0.2 \mu \mathrm{m}$.

The petrographical and physical characteristics, as well as its high resistance against salt crystallisation confer these rocks a high technical quality for their use as building stones in modern construction.

Keywords: Limestone, dolostone, decay, durability, pore size distribution

(*) Universidad de Zaragoza (Zaragoza, España). 


\section{INTRODUCCIÓN}

Conocer el sistema poroso de los materiales pétreos de usos constructivos es un aspecto fundamental puesto que controla su comportamiento físico-mecánico y condiciona su alterabilidad y/o durabilidad (1-2).

Las principales características necesarias para describir el sistema poroso de un material pétreo son su volumen, distribución de tamaños de poro, morfología de los mismos y la conexión de las diferentes familias porométricas entre sí (3-4). Estos parámetros son fundamentales para interpretar el comportamiento del material frente al agua (5) y para evaluar su durabilidad frente a procesos tales como la heladicidad (6-7) y la cristalización de sales (8). El comportamiento hídrico del material junto con las condiciones ambientales tras su puesta en obra, van a ser los factores que van a controlar principalmente la degradación de los materiales pétreos (9).

Para valorar la durabilidad de estas rocas se ha seleccionado el ensayo de cristalización de sales, ya que la cristalización de sales solubles en el interior del sistema poroso de los materiales pétreos se considera el principal mecanismo de deterioro que afecta a materiales pétreos tras su puesta en obra (10-19). La norma UNE 12370 indica que este ensayo debe realizarse en materiales con una porosidad superior al 5\%. Sin embargo, y dado el daño físico y químico que originan las sales al cristalizar en el interior o en la superficie de los materiales pétreos, este ensayo también presenta un notable interés para rocas con porosidad inferior al 5\% (20).

La consecuencia de la cristalización de sales en la piedra natural es el daño estructural y la pérdida de material. Por ello, es fundamental para evaluar la durabilidad de los materiales pétreos, caracterizar los cambios que tienen lugar en el sistema poroso tras la cristalización de sales.

Los materiales objeto de estudio son dos rocas carbonatadas de edad Cretácico superior (Turoniense superiorConiaciense) (21) que son explotadas en la actualidad como rocas ornamentales. En el presente trabajo vamos a referirnos a la variedad Abanto Pinta Morada (Biopelmicrita-Wackestone de bioclastos y peloides) como $A B-0$ y a la variedad cristalina como AB-2 (empleando las siglas asignadas en el estudio textural). Estas rocas son explotadas por la empresa Canteras Abanto en la cantera "Leonardo" ubicada en el término municipal de Abanto (Zaragoza), hoja del mapa geológico nacional 464 Used, escala 1:50.000 (Figura 1). Actualmente, estas rocas se comercializan con diferentes acabados (pulido, apomazado, flameado, envejecido, abujardado y en bruto) y los principales usos a los que son destinadas son aplacado y pavimentación tanto interior como exterior (Figura 2). La producción anual aproximada es de $4.500 \mathrm{~m}^{3}$.

\section{INTRODUCTION}

A knowledge of the pore system in stone materials used in construction, is essential, for it controls their physicalmechanical behaviour and conditions their alterability and/or durability (1-2).

The main parameters that describe the pore system in a stone are volume, pore size distribution, pore morphology and pore size family inter-connectivity (3-4). These parameters are essential for interpreting material behaviour when exposed to water (5) and evaluate durability in freeze-thaw (6-7) and salt crystallization (8) processes. Stone decay is governed primarily by hydraulic behaviour and the environmental conditions prevailing after it is laid (9).

The salt crystallization test was chosen to assess rock durability because the crystallization of soluble salts inside stone pore systems is regarded to be the chief decay mechanism in stone after it has been laid (10-19). Spanish standard UNE 12370 specifies that this trial must be conducted in all materials with a porosity of over $5 \%$. Nonetheless, in light of the physical and chemical damage caused by salts in stone interiors or surfaces, this test is of considerable utility in rocks with a porosity of under $5 \%$ (20) as well.

Salt crystallization in natural stone causes structural damage and loss of material. For that reason, the changes in the pore system after salt crystallization must be identified to evaluate stone durability.

The materials studied here were two Upper Cretaceous (Upper Turonian-Coniacian) carbonated rocks (21) presently quarried for ornamental use. In this paper the "Pinta Morada" (wackestone-biopelmicrite with bioclasts and peloids) variety is referred to as $A B-O$ and the crystalline variety as $A B-2$ (using the initials assigned in the textural study). These stones are quarried by Canteras Abanto at its "Leonardo" quarry located in the municipal district of Abanto in the Spanish province of Zaragoza (Used sheet 464 on the national geological map, scale 1:50.000 (Figure 1)). They are presently marketed with a number of finishes (polished, honed, flamed, aged, hammered and rough), primarily for use in indoor and outdoor flooring and tiling (Figure 2). Yearly output is on the order of $4500 \mathrm{~m}^{3}$. 


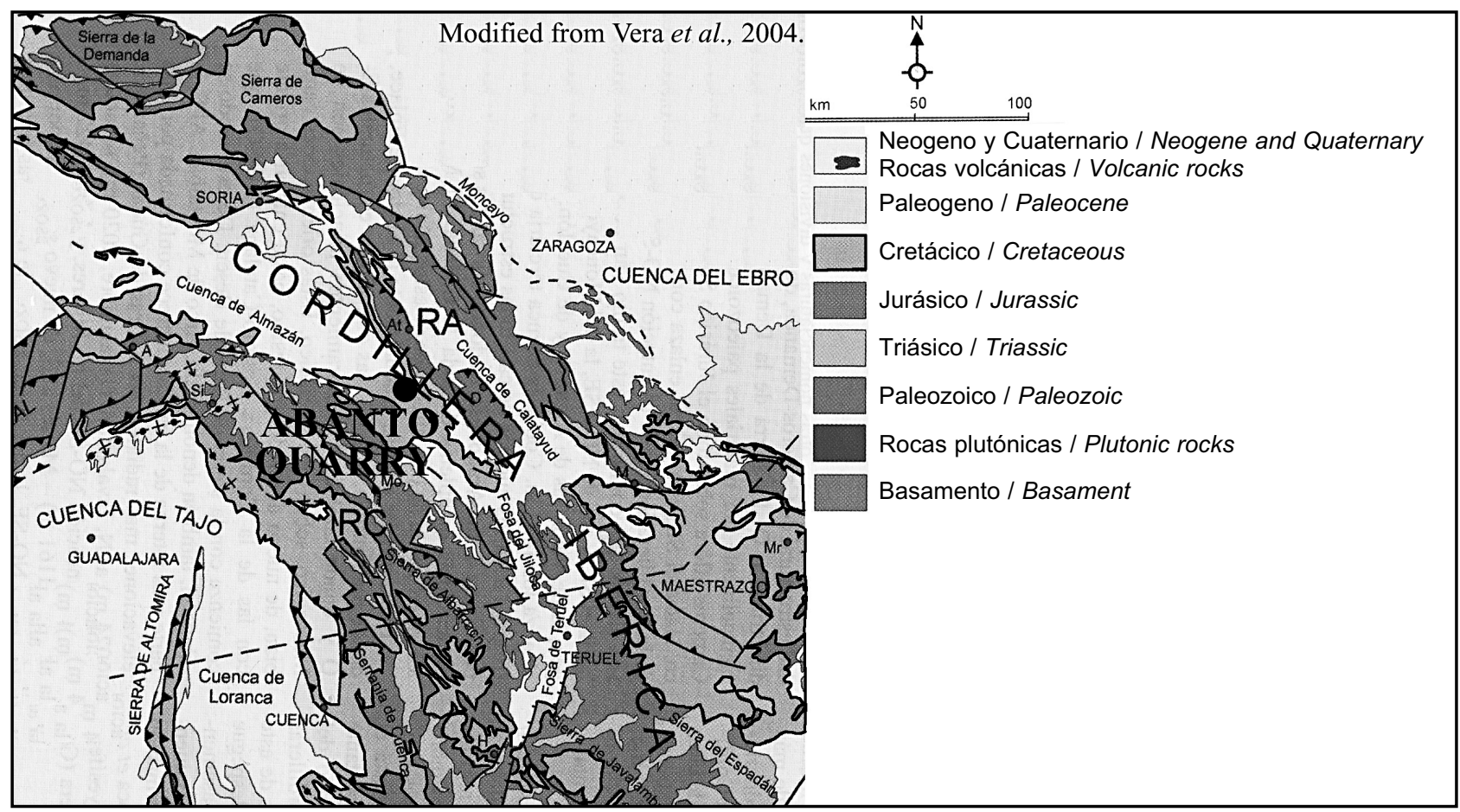

Figura 1. Mapa geológico de la cordillera Ibérica con la ubicación de la explotación (modificado de Vera et al., 2004 (22). RA (Rama Aragonesa), RC (Rama Castellana).

Figure 1. Geological map of the Iberian mountain range showing the quarry site (based on map in Vera et al., 2004 (22)). RA: Aragonese range; $R C$ : Castilian range.

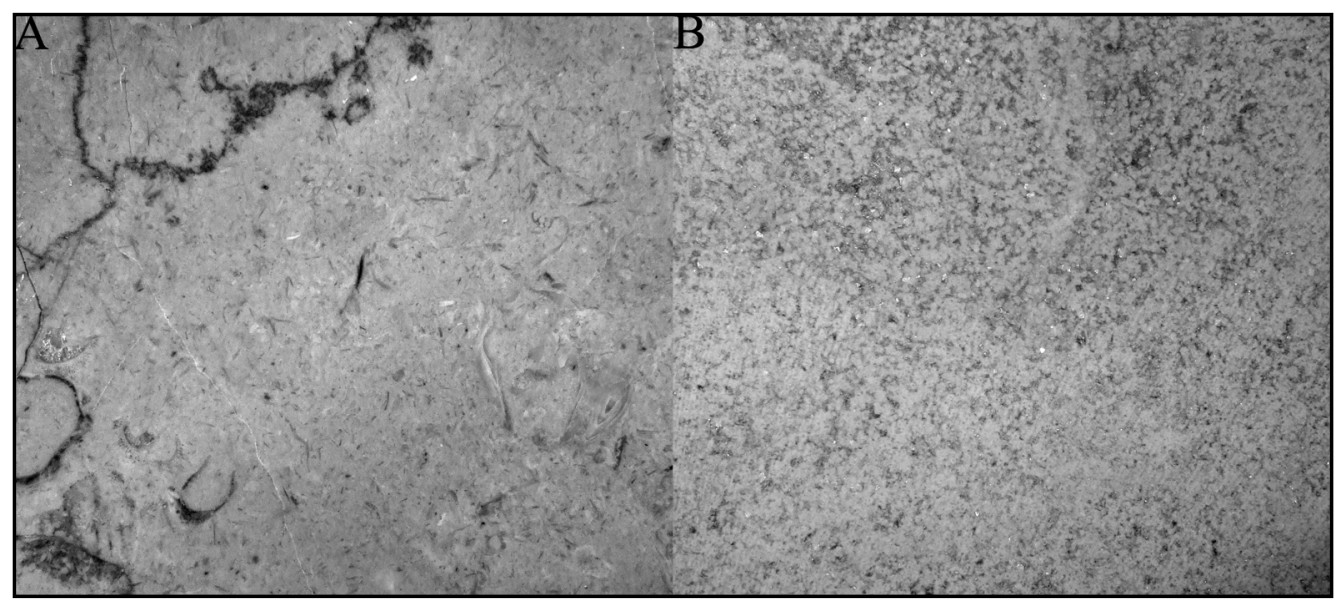

Figura 2. Aspecto de las rocas seleccionadas. A) AB-0 (Abanto Pinta Morada), B) AB-2 (Abanto Cristalina). Figure 2. Photo of selected rocks: A) AB-O ("Pinta Morada" Abanto), B) AB-2 (crystalline Abanto).

La explotación se localiza en la formación Embalse de La Tranquera, equivalente lateral de la formación Órganos de Montoro (21). Esta formación se caracteriza por presentar una sucesión litológica principalmente dolomítica, groseramente cristalina, de unos 70 metros de potencia total que se divide en dos tramos (21):

- El tramo inferior de 50 metros de potencia esta formado por dolomías claras masivas con fantasmas de biotopos de rudistas recristalizados. En los niveles menos afectados por procesos diagenéticos se
The quarry is sited in the Embalse de La Tranquera formation. The lateral equivalent to the Órganos de Montoro formation (21), it is characterized by a primarily dolomitic, coarsely crystalline lithological succession around 70 metres thick, divided into two courses (21):

- The lower course, $50 \mathrm{~m}$ thick, consists of massive light-coloured dolostone with phantom biotopes containing recrystallized rudistids. Packstone and grainstone are found in the levels less affected by 
observan texturas Packstone y Grainstone. El medio sedimentario se interpreta como un medio de depósito de plataforma interna restringida (23). En la parte alta de este tramo se localiza la explotación.

- El tramo superior de 20 metros de potencia, esta caracterizado por una parte inferior de carbonatos en paquetes dolomíticos con estratificación horizontal de aspecto masivo y una parte superior con un paquete que destaca regionalmente por su paleokarstificación, en el que además se observan geodas con cementación calcítica y rellenos arcillosos.

Los estratos calcáreos canterables presentan un espesor medio de 1 a 3 metros de potencia individual y se disponen en una serie homoclinal, con dirección media N120E y buzamientos generalmente suaves (inferiores al 150) hacia el suroeste. Se distinguen diferentes variedades litológicas en función del grado de desarrollo de los procesos de dolomitización, abarcando desde términos que no han sufrido dolomitización hasta otros completamente dolomitizados en los que se ha perdido la textura original.

Son abundantes los estilolitos de color marrón rojizo que conforman una retícula de densidad irregular, circunscritos a niveles concretos. El método de explotación es a cielo abierto con corte horizontal mediante rozadora de brazo y corte vertical con hilo diamantado. La potencia total de material explotable en la cantera estudiada es de aproximadamente 15 metros, presentando el frente de la explotación una altura de 6 metros y una longitud de 30 metros.

\section{EXPERIMENTAL}

La caracterización petrográfica (24) se realizó mediante el estudio de 25 láminas delgadas, con tinción de alizarina roja $S$ para la determinación de los porcentajes de calcita y dolomita, al microscopio óptico polarizante de luz trasmitida modelo Carl Zeiss Jena-Pol.

El análisis químico de elementos mayores se ha realizado mediante fluorescencia de rayos $X$ en el servicio de análisis de la Universidad de Granada. El equipo utilizado ha sido un espectrómetro secuencial de longitud de onda dispersiva con generador de rayos $X$ de 4 kw de potencia, con tubo de rayos $X$ de ventana ultrafina de ánodo de Rh. El equipo es de la marca Philips modelo PW2440 (MagiX-Pro). La preparación de muestras y patrones es en perla con una dilución 1:10 hecha con tetraborato de litio, y el equipo de preparación es una perladora Philips modelo Perl'x3.

El contenido en carbonato se ha determinado mediante el cálculo de la pérdida en peso por ignición (25). Esta técnica se basa en la interpretación de la pérdida en peso tras calentamientos escalonados a 200, 500 y diagenetic processes. The sedimentary depositional environment is interpreted to constitute a restricted internal platform (23). The quarry is located in the upper part of this course.

- $\quad$ The 20-metre thick upper course is characterized by a lower layer of carbonates found in massive, horizontally stratified dolomitic packages and an upper layer with a regionally prominent palaeokarstified package containing geodes with calcitic cementation and a clayey fill.

The quarriable calcareous strata range from one to three metres thick on average and have a homoclinal series with a mean direction of N120E and generally mild (under 150) south-westerly slopes. A number of lithological varieties can be distinguished, depending on the degree of dolomitization: from terminuses that have undergone none at all to others that are fully dolomitized, exhibiting total loss of the original texture.

In certain specific levels, a profusion of reddish-brown stylolites form a dense, irregular network. The quarry is an open-pit operation, with stone cut horizontally with a cutting chain and vertically with a diamond wire saw. The exploitable volume of the quarry studied is approximately 15 metres thick and 30 metres long, with a 6-metre front.

\section{EXPERIMENTAL}

Stone petrographic properties (24) were determined on 25 thin sections dyed with alizarine red $S$ to find the percentages of calcite and dolomite and observed under a Carl Zeiss Jena-Pol transmitted polarized light optical microscope.

The elemental analysis was conducted by the University of Granada's analytical laboratory service on a Philips PW2440 (MagiX-Pro) 4-kw sequential, wavelength dispersive spectrometer fitted with an ultrafine $R h$ anode window $X$-ray tube. Samples and controls were prepared as beads with a 1:10 dilution in lithium tetraborate using a Philips Perl'x3 bead maker.

The carbonate content was found by calculating loss on ignition (25), a technique based on interpreting the weight loss after heating the material at 200, 500 and $900{ }^{\circ} \mathrm{C}$, at which temperatures water, organic matter 
$900^{\circ} \mathrm{C}$, que corresponden a los contenidos de agua, materia orgánica y $\mathrm{CO}_{2}$ respectivamente. El residuo insoluble se ha determinado por gravimetría tras ataque ácido con $\mathrm{HCl} 0,8 \mathrm{~N}$ durante 2 horas a $70{ }^{\circ} \mathrm{C}$ con agitación. El residuo se ha recogido en filtro exento de cenizas y se ha calcinado en crisol de porcelana a $900{ }^{\circ} \mathrm{C}$ durante 90 minutos. La ganancia de peso del crisol, expresada en porcentaje en peso con relación al peso de muestra atacada, representa el residuo insoluble que corresponde al contenido de la fracción de minerales arcillosos, cuarzo y otros silicatos detríticos de la roca, no disueltos durante el ataque ácido. La determinación del contenido en carbonato y del residuo insoluble se ha realizado en el laboratorio del Área de Petrología y Geoquímica del Departamento de Ciencias de la Tierra de la Universidad de Zaragoza.

La caracterización física se ha realizado, en todos los casos posibles, siguiendo las recomendaciones de las normas UNE (26-28). Los ensayos físicos realizados han sido: absorción y desorción de agua, absorción de agua por capilaridad, porosidad abierta y total y densidad aparente y real. Todos los ensayos realizados para cada tipo litológico se han efectuado sobre la misma tanda de 6 probetas cúbicas de $5 \mathrm{~cm}$ de aristas extraídas de un mismo bloque. La realización de los diferentes ensayos sobre la misma tanda de 6 probetas ha permitido obtener unos resultados más representativos evitando posibles variaciones por la heterogeneidad del material. Las variedades ensayadas han sido $A B-0$ y $A B-2$ que son actualmente las únicas variedades en explotación.

La distribución de tamaño de radios de acceso de poro se ha determinado mediante porosimetría de inyección de mercurio. Los equipos utilizados han sido los porosímetros Pascal 140 (macroporosidad) y Pascal 240 (microporosidad). El tamaño de radios de acceso de poros registrado por el equipo comprende de 0,001 a $1260 \mu \mathrm{m}$ (de 0,001 a $10 \mu \mathrm{m}$ el microporosímetro y de 10 a $1260 \mu \mathrm{m}$ el macroporosímetro). Las probetas utilizadas fueron cilíndricas de $3 \mathrm{~cm}$ de altura y $0,5 \mathrm{~cm}$ de diámetro.

El comportamiento dinámico se ha evaluado mediante la medida de la velocidad de propagación de las ondas elásticas longitudinales $\mathrm{V}_{\mathrm{p}}$. El equipo de ultrasonidos utilizado ha sido el Ultrasonic tester C-370.

La caracterización de estos materiales se ha completado con la evaluación de su durabilidad frente a los procesos de cristalización de sales. El ensayo realizado ha sido el de envejecimiento artificial acelerado de cristalización de sales (29). Para evaluar el deterioro en estas rocas se ha medido la pérdida en peso a lo largo del ensayo y se documentó el deterioro visual generado. and $\mathrm{CO}_{2}$ volatize, respectively. The insoluble residue was found by gravity after acid attack with $0.8 \mathrm{~N} \mathrm{HCl}$, stirred for $2 h$ at $70{ }^{\circ} \mathrm{C}$. The ash-free residue left after the solution was filtered was burnt in a porcelain crucible at $900{ }^{\circ} \mathrm{C}$ for 90 minutes. The insoluble residue was regarded to account for the increase in crucible weight expressed as a per cent of the total weight of the sample attacked. This residue contained the fraction of clayey and quartz minerals and other detrital silicates in the rock that were not dissolved by the acid. The carbonate content and insoluble residue were determined at the Petrology and Geochemical Laboratory in the University of Zaragoza's Department of Earth Science.

Wherever possible, the physical properties were analyzed pursuant to Spanish UNE standard recommendations (26-28). The tests conducted included: water absorption and desorption, capillary water uptake, effective and total porosity and bulk and real density. All the tests performed for each stone type were conducted on a series of six 5-cm cubic specimens, all cut from the same block. Conducting different tests on the same series of six specimens yielded more representative results and avoided possible variations attributable to material heterogeneity. The varieties tested were $A B-0$ and $A B-2$, the only two varieties currently being quarried.

The pore throat size distribution was found with mercury injection porosimetry on Pascal 140 (macroporosity) and Pascal 240 (microporosity) porosimeters. The pore throat radius readings ranged from 0.001 to $1260 \mu \mathrm{m}$ (from 0.001 to $10 \mu \mathrm{m}$ on the micro porosimeter and from 10 to $1260 \mu \mathrm{m}$ on the macroporosimeter). Cylindrical specimens were used, measuring $3 \mathrm{~cm}$ high and $0.5 \mathrm{~cm}$ in diameter.

Dynamic behaviour was analyzed by measuring the elastic longitudinal wave velocity, $v_{p \prime}$ on a $C-370$ ultrasonic tester.

Finally, the durability of these materials was evaluated with the accelerated salt crystallization test (29), in which rock decay was assessed in terms of the weight loss throughout the trial as well as visual decay, which was also monitored and recorded. 


\section{RESULTADOS}

\subsection{Análisis petrológico y geoquímico}

\section{Variedad cristalina}

Microscópicamente la roca $A B-2$, única variedad que se encuentra actualmente en explotación dentro de este nivel, tiene un aspecto masivo, tamaño cristalino medio y color naranja grisáceo (10R 8/2) (30). Es una roca muy homogénea con zonas esparíticas, apreciables a simple vista, de hasta $1 \mathrm{~cm}$ de diámetro. No presenta ningún tipo de discontinuidad.

Dentro del nivel dolomitizado, el análisis petrográfico realizado sobre las muestras recogidas en cantera ha permitido identificar dos tipos principales: dolomías cristalinas (31) ( $A B-1$ y $A B-3)$ y calizas cristalinas ( $A B-2$ y $A B-4)$. Tal y como se observa en la Figura 3, la mayor parte del volumen canterable corresponde a las primeras, quedando las calizas cristalinas como intercalaciones de menor espesor. Todas estas rocas muestran al microscopio la destrucción de la textura deposicional original. Composicionalmente están constituidas casi exclusivamente por dolomita y calcita, alcanzando la dolomita un porcentaje de entre el 80 y el $90 \%$ en las dolomías cristalinas estudiadas; por otra parte, la proporción de dolomita en las rocas de tipo caliza cristalina varía entre el $30 \%$ en la $A B-2$ y el $10 \%$ en la $A B-4$.

\section{RESULTS}

\subsection{Petrological and geochemical analysis}

\section{Crystalline variety}

Microscopically, rock $A B-2$, the sole variety presently quarried at this level, is massive in appearance, with medium-sized, greyish-orange crystals (10R 8/2) (30). A very homogeneous rock with clearly visible sparitic areas up to $1 \mathrm{~cm}$ in diameter, it is free of discontinuities.

The petrographic analysis of the samples taken in the dolomitized layer revealed the existence of two main types: crystalline dolostones (31) ( $A B-1$ and $A B-3)$ and crystalline limestone ( $A B-2$ and $A B-4)$. As Figure 3 shows, the former account for most of the quarriable volume, while the crystalline limestone is found in thinner intercalations. The microscopic study showed that the original depositional structure had been destroyed in all these rocks. Their composition consists almost exclusively of dolomite and calcite, with dolomite constituting from 80 to $90 \%$ in the crystalline dolostones studied and just $30 \%$ in the $A B-2$ variety of crystalline limestone and $10 \%$ in variety $A B-4$.

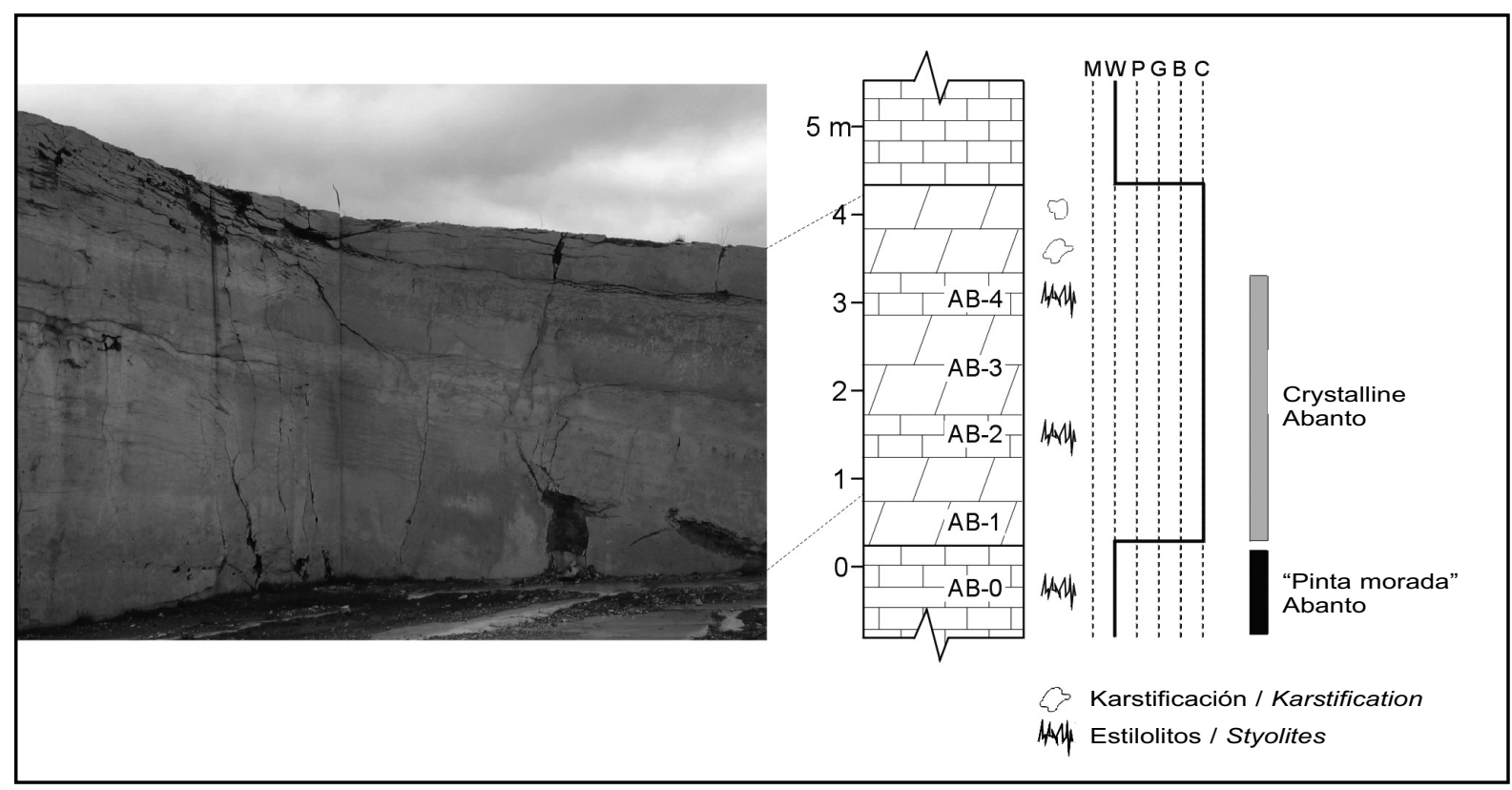

Figura 3. Aspecto de una zona del frente de cantera estudiado, y columna litológica con localización de las muestras recogidas y evolución textural observada en la vertical del frente (M- Mudstone, W- Wackestone, P- Packstone, G- Grainstone, B- Boundstone y C-Carbonatos cristalinos).

Figure 3. Front of the quarry studied and lithological column showing location of samples and textural variations observed vertically along the front. ( $M$ - mudstone, W-Wackestone, P-Packstone, G-Grainstone, B-Boundstone and C-Crystalline carbonate). 
El proceso de dolomitización que ha afectado a estas rocas durante la diagénesis ha destruido las características texturales originales de depósito (Figura 4B, C y D), dando lugar a texturas de reemplazamiento constituidas por mosaicos cristalinos que, según la terminología de Sibley y Gregg (32), se corresponden con texturas de tipo "no planar" (predominante en $A B-2$ y $A B-4$ ) y de tipo "planar-s" (predominante en $A B-1$ y $A B-3$ ). Se observa además un incremento progresivo en el tamaño de los cristales que conforman el mosaico de recristalización hacia el techo de la columna, desde un promedio de 300 $\mu \mathrm{m}$ en la muestra AB-2 hasta $600 \mu \mathrm{m}$ en la AB-4. La tinción realizada ha permitido observar procesos de dedolomitización en todas las rocas aquí estudiadas, ya que parte del mosaico formado durante la dolomitización presenta actualmente composición calcítica.
The dolomitization that took place during rock diagenesis destroyed the original texture of the materials deposited (Figures $4 B, C$ and D), giving rise to replacement textures. These crystalline mosaics were found to be either "non-planar" (prevalent in $A B-2$ and $A B-4$ ) or "splanar" (prevalent in $A B-1$ and $A B-3$ ), to use the Sibley and Gregg (32) terminology. The size of the crystals in the mosaic was observed to rise gradually with column height, from a mean of $300 \mu \mathrm{m}$ in sample $A B-2$ to 600 $\mu m$ in $A B-4$. The dye revealed de-dolomitization in all the rocks studied, for part of the mosaic that formed during dolomitization is now calcitic.

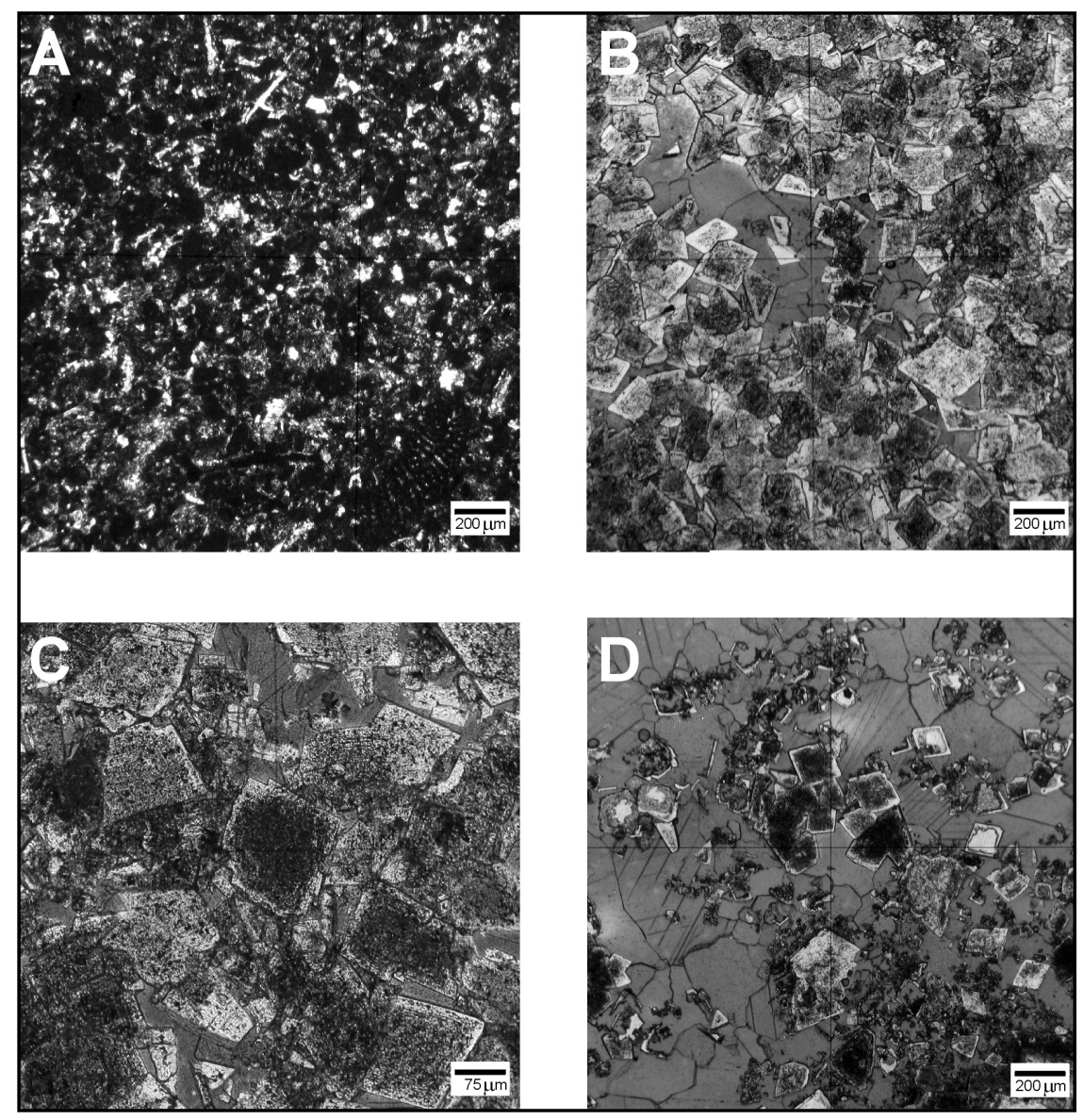

Figura 4. Fotografías de algunas de las muestras estudiadas mediante microscopio petrográfico, tomadas todas ellas con nícoles paralelos. A) Muestra AB-0, Wackestone-biopelmicrita. B) Muestra AB-1, dolomía cristalina. C) Muestra AB-2, caliza cristalina por procesos de dedolomitización. D) Muestra AB-3, dolomía cristalina (localmente cementstone).

Figure 4. Microphotographs of the samples studied, taken with parallel Nicol prisms: A) sample AB-0, wackestone-biopelmicrite; $B$ ) sample $A B-1$, crystalline dolostone; $C$ ) sample $A B-2$, de-dolomitized crystalline limestone; $D$ ) sample $A B-3$, crystalline dolostone (locally, cement stone).

El sistema poroso de estas rocas está constituido por porosidad secundaria intercristalina, generada durante el proceso de dolomitización. Esta porosidad, constituida
The inter-crystalline secondary pore system in these rocks was generated during dolomitization. This porosity, characterized by large cavities, was found to contain 
por oquedades de gran tamaño, aparece ocupada por cemento esparítico calcítico en mosaico equigranular o en ocasiones poiquilotópico. También se observa la existencia de porosidad secundaria de fractura, igualmente rellena por cemento esparítico calcítico.

\section{Variedad abanto pinta morada}

Macroscópicamente la roca tiene un aspecto masivo, de color naranja muy pálido (10YR 8/2) con abundantes estilolitos de color marrón rojizo medio (10R 4/6) y tamaño de grano fino. Presenta fracturas abiertas, ocasionalmente con relleno calcítico y poros aislados de hasta $1 \mathrm{~cm}$ de diámetro. Se encuentran fragmentos de fósiles de hasta $1 \mathrm{~cm}$ de longitud.

El estudio petrográfico indica que las rocas de esta variedad (Figura 4A) no han sufrido transformaciones diagenéticas capaces de destruir la textura original de depósito. Así, la roca AB-0, representativa de este nivel, es un wackestone-biopelmicrita (33-34) con textura granuda variable, predominantemente sostenida por la matriz, pero con zonas de textura granosostenida. Los aloquímicos son bioclastos $13-18 \%$ (bivalvos, foraminíferos y equinodermos, con un buen estado de conservación) y peloides $4-6 \%$. La matriz micrítica y los granos micríticos suponen el $50 \%$ de la roca. Es una roca bien cementada con un $23-27 \%$ de cemento de calcita esparítica dispuesto principalmente en mosaicos de tamaño equigranular. Este cemento se localiza en el espacio intergranular, rellenando parte de la porosidad móldica de los bioclastos y sellando parte de la porosidad de fractura. Son rocas de composición calcítica en su práctica totalidad, tal y como se puede comprobar en la Tabla 1. sparry calcitic cement with an equigranular or occasionally a poikilophthic mosaic. Secondary fracture porosity was also observed, likewise filled with sparry calcitic cement.

\section{'Pinta Morada' Abanta variety}

Macroscopically, the rock was observed to be massive with a pale orange (10YR 8/2) colour, numerous medium reddish brown (10R 4/6) stylolites and a fine particle size. It contained open fractures, occasionally with calcitic filling and isolated pores up to $1 \mathrm{~cm}$ in diameter. Fossil fragments up to $1 \mathrm{~cm}$ long were found.

Further to the petrographic study, this variety of rock (Figure 4A) underwent no diagenetic transformations able to destroy the original depositional texture. Rock $A B-0$, representative of this level, was found to be a wackestone-biopelmicrite (33-34) with a variable texture, Predominantly Mud supported but with a few Grain supported areas. The allochemical metamorphisms were bioclasts (well conserved bivalves, foraminifers and echinoderms), $13-18 \%$, and peloids, $4-6 \%$. The micritic matrix and grains accounted for $50 \%$ of the rock. This well cemented rock had $23-27 \%$ sparry calcitic cement, primarily forming equigranular mosaics. The cement was located in the intergranular space, partially filling the mould porosity attributable to the bioclasts and partially sealing the fracture porosity. These rocks are nearly entirely calcitic, as may be deduced from Table 1.

Tabla 1 / Table 1

Resultado del análisis geoquímico de elementos mayores expresados en porcentaje en peso de óxidos. Elemental analysis findings expressed in oxide percentage (wt).

\begin{tabular}{|c|c|c|c|c|c|c|c|c|c|c|c|c|}
\hline & $\mathrm{Al}_{2} \mathrm{O} 3(\%)$ & $\mathrm{CaO}(\%)$ & $\mathrm{Fe}_{2} \mathrm{O} 3(\%)$ & $\mathrm{K}_{2} \mathrm{O}(\%)$ & $\mathrm{MgO}(\%)$ & $\mathrm{MnO}(\%)$ & $\mathrm{Na}_{2} \mathrm{O}(\%)$ & $\mathrm{P}_{\mathbf{2}} \mathrm{O} 5(\%)$ & $\mathrm{SiO}_{2}(\%)$ & $\mathrm{TiO}_{2}(\%)$ & LOI (\%) & Total \\
\hline $\mathrm{AB}-0$ & 0.170 & 55.632 & 0.044 & 0.020 & 0.389 & $<\mathrm{LLD}$ & 0.047 & $<\mathrm{LLD}$ & 0.300 & 0.007 & 43.030 & 99.639 \\
\hline $\mathrm{AB}-2$ & 0.225 & 44.070 & 0.069 & 0.024 & 9.490 & $<\mathrm{LLD}$ & 0.129 & $<\mathrm{LLD}$ & 0.397 & $<\mathrm{LLD}$ & 44.710 & 99.114 \\
\hline
\end{tabular}

La caracterización geoquímica de ambas variedades (Tablas 1 y 2), realizada sobre muestras inalteradas, aporta información sobre la composición química de los materiales. El residuo insoluble es bajo en ambas variedades, y la principal diferencia existente entre los análisis geoquímicos de elementos mayores obtenidos por fluorescencia de rayos $X$ es el elevado porcentaje en $\mathrm{MgO}(9,49 \%)$ en $\mathrm{AB}-2$ que, junto con el estudio petrográfico, se explica por la presencia de dolomita entre su mineralogía. Ambas rocas presentan valores bajos de $\mathrm{SiO}_{2}, \mathrm{Al}_{2} \mathrm{O}_{3}, \mathrm{~K}_{2} \mathrm{O}, \mathrm{Na}_{2} \mathrm{O}$ y $\mathrm{Fe}_{2} \mathrm{O}_{3}$ aunque son ligeramente superiores en $\mathrm{AB}-2$.
Unaltered samples of the two varieties (Tables 1 and 2) were analyzed for their geochemical composition. The insoluble residue was small in both varieties. The primary difference in the $X$-ray fluorescence findings for the two was the high percentage of $\mathrm{MgO}$ (9.49\%) in $\mathrm{AB}-2$, which would be explained by the presence of dolomite in its mineralogical composition, as detected in the petrographic study. While both rocks had low $\mathrm{SiO}_{2}$, $\mathrm{Al}_{2} \mathrm{O}_{3}, \mathrm{~K}_{2} \mathrm{O}, \mathrm{Na}_{2} \mathrm{O}$ and $\mathrm{Fe}_{2} \mathrm{O}_{3}$ contents, the values were slightly higher in $A B-2$. 
Caracterización del sistema poroso y de su influencia en el deterioro por cristalización de sales en calizas y dolomías explotadas en Abanto (Zaragoza, España) Characterization of pore system and their influence on decay rates caused by salt weathering on limestones and dolostones quarried in Abanto (Zaragoza, Spain)

Tabla 2 / Table 2

Valores del contenido de agua, materia orgánica, $\mathrm{CO}_{2}$ y residuo insoluble, expresados en porcentaje. Water content, organic matter, $\mathrm{CO}_{2}$ and insoluble residue, in per cent.

\begin{tabular}{|c|c|c|c|c|}
\hline & \% $_{\mathbf{2}} \mathbf{O}$ & $\%$ O. M. & $\% \mathrm{CO}_{\mathbf{2}}$ & \% I. R. \\
\hline $\mathrm{AB}-0$ & 0.134 & 0.267 & 43.366 & 0.611 \\
\hline $\mathrm{AB}-2$ & 0.134 & 0.697 & 44.584 & 0.467 \\
\hline
\end{tabular}

\subsection{Características del sistema poroso}

Los resultados de los ensayos hídricos se muestran en la Tabla 3. Ambas rocas presentan unos valores reducidos de porosidad abierta, siendo de $3,43 \%$ en $A B-2$ y de $0,65 \%$ en $A B-0$, absorción y coeficiente de saturación a 1 hora (siendo especialmente reducido en $A B-0$ con un valor de $23,44 \%$ ). La densidad real en $A B-0$ es elevada, debido a que se trata de una caliza muy pura, con valores de $2.708 \mathrm{~kg} / \mathrm{m}^{3}$ próximos al valor teórico de densidad real de la calcita, mientras que $A B-2$ con composición más dolomítica presenta una densidad ligeramente inferior, $2.690 \mathrm{~kg} / \mathrm{m}^{3}$, por las impurezas que posee.

\subsection{Pore system}

The results of the hydric tests are given in Table 3. Both rocks had small effective porosity values: $3.43 \%$ in $A B-2$ and $0.65 \%$ in $A B-0$, as well as low absorption and 1-hour saturation coefficients (particularly in $A B-0$, at 23.44\%). As a very pure limestone, $A B-0$ exhibited high real density, with values of $2708 \mathrm{~kg} / \mathrm{m}^{3}$, very close to the theoretical value for calcite, while $A B-2$, with a greater prevalence of dolomites in its composition, had a slightly lower density, $2690 \mathrm{~kg} / \mathrm{m}^{3}$, due to its impurities.

Tabla 3 / Table 3

Parámetros hídricos (promedio de 6 probetas). Absorción W, coeficiente de saturación a 1 hora $\mathrm{S}_{1}$, porosidad abierta $\mathrm{P}_{0}$, densidad real $\rho_{\mathrm{r}}$, contenido de agua en desorción $\mathrm{W}_{\mathrm{d}}$, contenido en agua crítico $\mathrm{W}_{\mathrm{cri}}$ coeficiente de absorción capilar C.A.C. y saturación capilar $\mathrm{S}_{\mathrm{c}}$. Hydric parameters (mean of six specimens). Absorption $(W), 1$-h saturation coefficient $\left(S_{1}\right)$, effective porosity $\left(P_{0}\right)$, real density $\left(r_{r}\right)$, desorption water content $\left(W_{d}\right)$, critical water content $\left(W_{c r i}\right)$, capillary absorption coefficient (C.A.C.) and capillary saturation $\left(S_{c}\right)$.

\begin{tabular}{|c|c|c|c|c|c|c|c|c|}
\hline & $\mathbf{W}(\%)$ & $\mathbf{S}_{\mathbf{1}}(\%)$ & $\mathbf{P}_{\mathbf{0}}(\%)$ & $\mathbf{r}_{\mathbf{r}}\left(\mathbf{k g} / \mathbf{m}^{3}\right)$ & $\mathbf{W}_{\mathbf{d}}(\%)$ & $\mathbf{W}_{\text {cri }}(\%)$ & $\mathbf{C . A . C}\left(\mathbf{g} / \mathbf{m}^{2} \mathbf{s}^{-0,5}\right)$ & $\mathbf{S}_{\mathbf{c}}(\%)$ \\
\hline$A B-0$ & $0.24 \pm 0.04$ & 23.44 & $0.65 \pm 0.19$ & $2708 \pm 2.43$ & 0.041 & 23.25 & $1.31 \pm 1.04$ & 7.54 \\
\hline$A B-2$ & $1.32 \pm 0.17$ & 53.93 & $3.43 \pm 0.42$ & $2690 \pm 23.56$ & 0.036 & 38.52 & $10.4 \pm 0.99$ & 68.6 \\
\hline
\end{tabular}

Las gráficas de absorción para estas rocas (Figura 5A) se descomponen en dos rectas con un cambio de pendiente gradual entre la fase inicial y la fase final.

Las gráficas de desorción para estas rocas (Figura 5B) muestran como la roca $\mathrm{AB}-0$ posee una evaporación muy rápida perdiendo el $83 \%$ del agua de saturación en pocos segundos, mientras que en $A B-2$ el proceso es más lento, en general, menos eficaz, que genera un mayor tiempo de permanencia de la humedad en el interior del sistema poroso. La retención de agua tras secado es similar para ambas rocas, $0,041 \%$ en $A B-0$ y $0,036 \%$ en $A B-2$.

Las gráficas de absorción capilar muestran la variación en el tiempo del contenido en agua del material adquirido por el mecanismo de succión capilar (Figura $5 \mathrm{C}$ ). La roca $A B-0$ presenta un coeficiente de succión capilar $\left(1,31 \mathrm{~g} / \mathrm{m}^{2} \mathrm{~s}^{-0,5}\right)$ y una saturación capilar muy reducida $(7,54 \%)$, consecuencia de un sistema poroso heterogéneo con una baja conectividad, en el que existen variaciones en el tamaño de los poros o en sus conexiones. La roca AB-2 presenta valores más elevados para estos coeficientes y la gráfica de absorción capilar se descompone en dos rectas con un cambio de pendiente neto entre la fase inicial y la final.
The absorption curves for these rocks (Figure 5A) could be broken down into two straight lines exhibiting a gradual change of slope between the initial and final phase.

Their desorption curves (Figure 5B), in turn, showed that rock $A B-0$ underwent evaporation rapidly, losing $83 \%$ of the saturation water in a matter of a few seconds. The process was generally slower and less effective in $A B-2$, where moisture was retained inside the pore system longer. Water retention after drying was similar in the two rocks, $0.041 \%$ in $A B-0$ and $0.036 \%$ in $A B-2$.

The capillary absorption curves showed the variation in the capillary suction-induced water content over time for the material (Figure 5C). Rock $A B-0$ exhibited very low capillary suction $\left(1.31 \mathrm{~g} / \mathrm{m}^{2} \mathrm{~s}^{-0,5}\right)$ and capillary saturation (7.54\%) values as a result of scant connectivity and variations in pore size or inter-pore connections. Rock $A B-2$ had higher values for these coefficients and a capillary absorption curve that could be broken down into two straight lines with a net change of slope between the initial and final phases. 


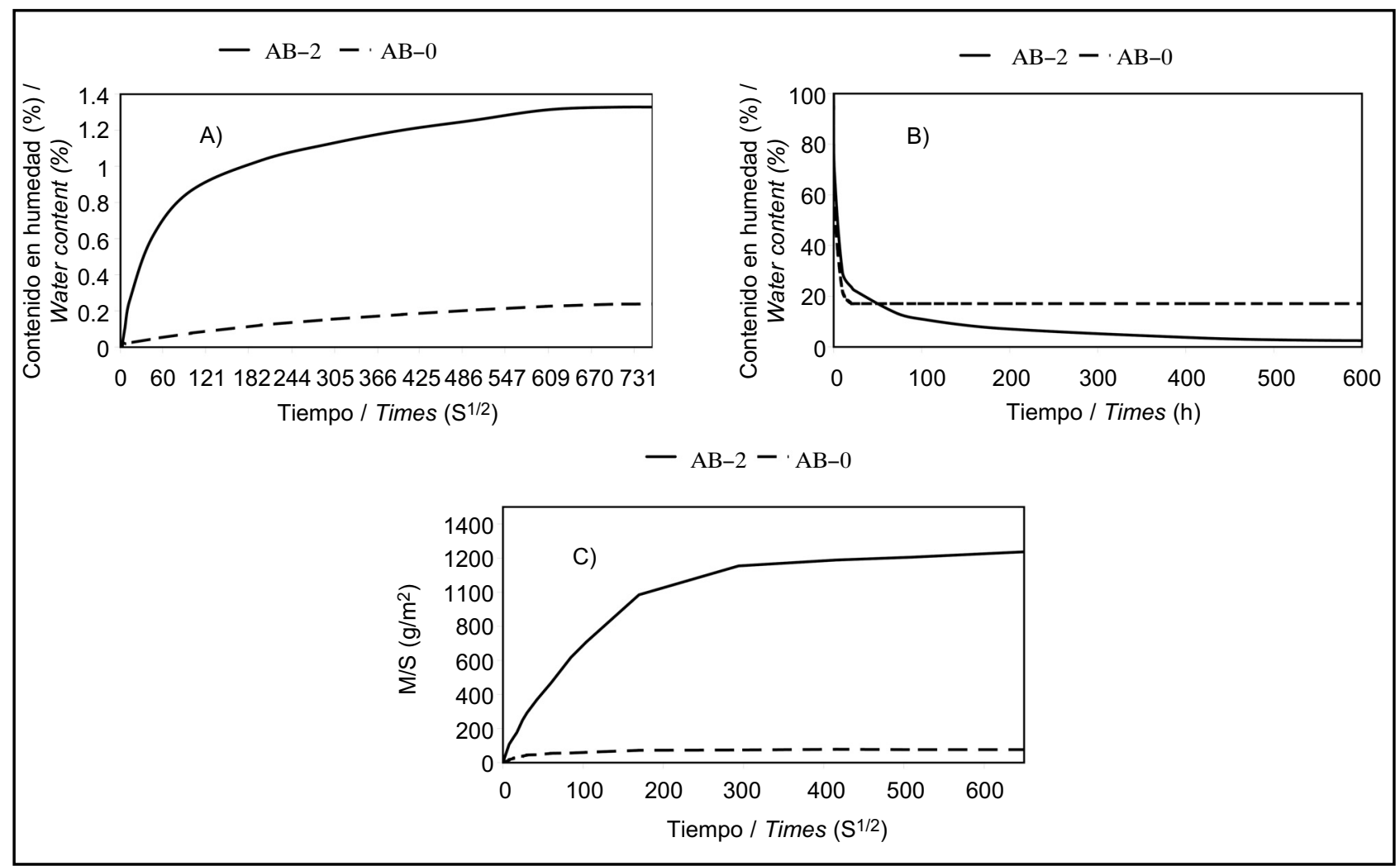

Figura 5. Comportamiento hídrico: A) curvas de absorción libre de agua, B) curvas de evaporación y C) curvas de absorción capilar. Figure 5. Hydric behaviour: A) water-free absorption curves; B) evaporation curves; C) capillary absorption curves.

A partir de los resultados obtenidos con la porosimetría de inyección de mercurio se han calculado diferentes parámetros resumidos en la Tablas 4 y 5 . Además, se han construido histogramas de frecuencia de distribución de radios de acceso de poro para cada una de las rocas caracterizadas. En esta investigación se ha considerado microporosidad el volumen de poros con radios de acceso inferiores a 7,5 $\mu \mathrm{m}(3,35-36)$.
The mercury injection porosimetry findings were used to calculate the parameters summarized in Tables 4 and 5. Pore throat size frequency distribution charts were also built for the rocks characterized. In this study, microporosity was regarded to be the volume of pores with throat radii of under $7.5 \mu \mathrm{m}(3,35-36)$.

Tabla 4 / Table 4

Valores de macroporosidad, microporosidad, mediana, tamaño medio de radio de acceso y tamaños máximos de radio de acceso obtenidos por porosimetría de inyección de mercurio. El valor entre paréntesis indica el valor del radio medio de la microporosidad.

Mercury injection porosimetry findings: macroporosity, microporosity and median, average and maximum pore throat size. In parenthesis: mean micropore size.

\begin{tabular}{|c|c|c|c|c|c|}
\hline & $\begin{array}{c}\text { Macroporosidad / } \\
\text { Macroporosity (\%) }\end{array}$ & $\begin{array}{c}\text { Microporosidad / } \\
\text { Microporosity (\%) }\end{array}$ & $\begin{array}{c}\text { Mediana / Median } \\
(\boldsymbol{\mu m})\end{array}$ & $\begin{array}{c}\text { Radio medio / } \\
\text { Average pore size } \\
(\boldsymbol{\mu m})\end{array}$ & $\begin{array}{c}\text { Máximos / Maximum } \\
(\boldsymbol{\mu m})\end{array}$ \\
\hline $\mathrm{AB}-0$ & 0.08 & 0.81 & 0.04 & $(0.0057) 0.18$ & $0.025-0.0110-9$ \\
\hline $\mathrm{AB}-2$ & 0.25 & 6.89 & 0.25 & $(0.27) 0.27$ & $0.3-0.2$ \\
\hline
\end{tabular}

Tabla 5 / Table 5

Porcentaje de volumen de accesos de poro para los principales rangos de tamaño de acceso de poro. Volume of main pore throat size ranges, in per cent.

\begin{tabular}{|c|c|c|c|c|c|}
\hline & $\mathbf{0 . 0 0 1 - 0 . 0 1} \boldsymbol{\mu m}$ & $\mathbf{0 . 0 1 - 0 . 1} \boldsymbol{\mu m}$ & $\mathbf{0 . 1 - 1} \boldsymbol{\mu m}$ & $\mathbf{1 - 1 0} \boldsymbol{\mu m}$ & $>\mathbf{m} \boldsymbol{\mu m}$ \\
\hline $\mathrm{AB}-0$ & $16.60 \%$ & $69.88 \%$ & $3.18 \%$ & $10.31 \%$ & $0.00 \%$ \\
\hline $\mathrm{AB}-2$ & $1.370 \%$ & $15.390 \%$ & $79.71 \%$ & $0.88 \%$ & $2.65 \%$ \\
\hline
\end{tabular}


La roca $A B-0$ se caracteriza por presentar una distribución bimodal y asimétrica negativa de sus accesos de poro (Figura 6 ) con más del $86 \%$ de sus radios de acceso de poro inferiores a $0,1 \mu \mathrm{m}$, mientras que la roca AB-2 se caracteriza por una distribución unimodal de sus tamaños de acceso de poro con el $79 \%$ de su volumen de accesos de poros pertenece al rango 0,1-1 $\mu \mathrm{m}$. La roca $A B-0$, al igual que otros materiales pétreos de usos constructivos (37), presenta dos familias porométricas. Una microporosidad del $92 \%$ con tamaño medio 0,0057 $\mu \mathrm{m}$ que controla su comportamiento hídrico y una macroporosidad del $8 \%$ debida a estilolitos y vénulas parcialmente rellenas que eleva el tamaño de acceso medio a 0,18 $\mu \mathrm{m}$. Ésta es una porosidad secundaria no selectiva de la fábrica.
In rock $A B-0$, pore throat size exhibited a bimodal distribution with negative asymmetry (Figure 6). Over $86 \%$ of its pores had throat radii smaller than $0.1 \mu \mathrm{m}$. The distribution in rock $A B-2$, in turn, was unimodal, with $79 \%$ of its pore throat volume falling in the 0.1-1 $\mu \mathrm{m}$ range. Rock $A B-0$, like other stone materials used in construction (37), was found to have two porometric families: a micropore family which, with a mean pore throat size of $0.0057 \mu \mathrm{m}$, controlled its hydric behaviour and accounted for $92 \%$ of the total, and a macropore family (8\%) comprising stylolites and tiny, partially occluded veins that raised the mean pore throat size to $0.18 \mu \mathrm{m}$. This porosity was secondary and non-selective.
AB-0

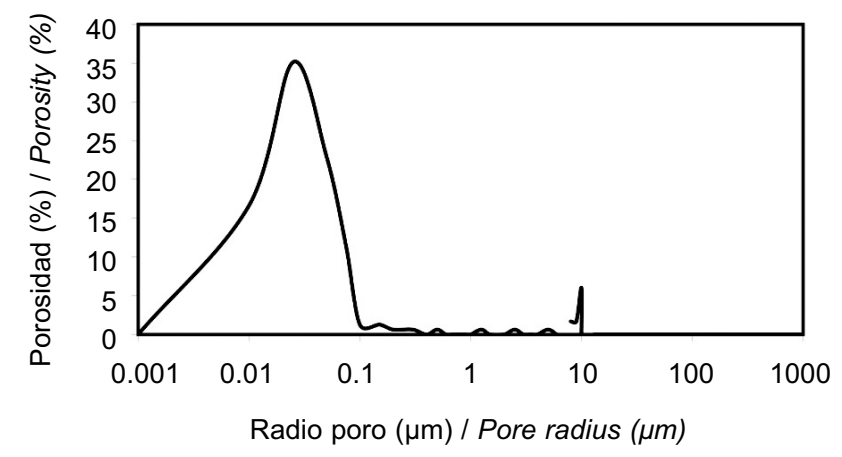

AB-2

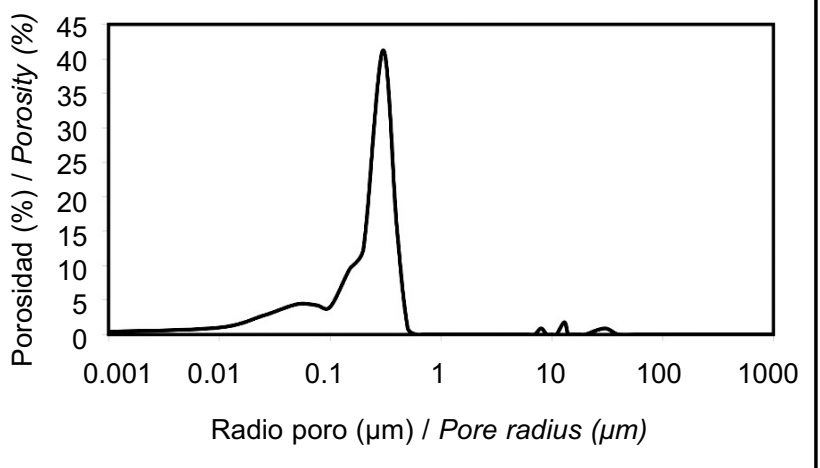

Figura 6. Distribución porométrica de $\mathrm{AB}-0$ y $\mathrm{AB}-2$.

Figure 6. Pore size distribution in $A B-0$ and $A B-2$.

\subsection{Propiedades dinámicas. Velocidad de propagación de las ondas $V_{p}$}

Se han determinado los valores de velocidad de ultrasonidos en dos direcciones perpendiculares (Tabla 6). La roca $A B-0$ presenta una velocidad media de propagación de ultrasonidos de $6.491 \mathrm{~m} / \mathrm{s}$ (variando de 6.135 a $6.784 \mathrm{~m} / \mathrm{s}$ ) mientras que la roca $A B-2$ presenta una velocidad media de propagación de ultrasonidos $6.090 \mathrm{~m} / \mathrm{s}$ (variando de 5.775 a $6.454 \mathrm{~m} / \mathrm{s})$.

\subsection{Dynamic properties. Wave velocity, $V_{p}$}

Ultrasound velocity values were determined in two perpendicular directions (Table 6). The mean value found for rock $A B-0$ was $6491 \mathrm{~m} / \mathrm{s}$ (fluctuating from 6135 to $6784 \mathrm{~m} / \mathrm{s}$ ), while the mean ultrasound velocity recorded for $A B-2$ was 6090 m/s (ranging from 5775 to $6454 \mathrm{~m} / \mathrm{s})$.

Tabla 6 / Table 6

Valores de la velocidad de transmisión de ondas ultrasónicas (en $\mathrm{m} / \mathrm{s})$ perpendicular a la estratificación $\left(\mathrm{Vp}_{1}\right)$ y paralela $\left(\mathrm{Vp}_{2}\right)$. Ultrasound wave velocity (in $\mathrm{m} / \mathrm{s}$ ), perpendicular $\left(V p_{1}\right)$ and parallel $\left(V p_{2}\right)$ to the bedding plane.

\begin{tabular}{|c|c|c|}
\hline & $\mathbf{V}_{\mathbf{p} 1}(\mathbf{m} / \mathbf{s})$ & $\mathbf{v}_{\mathbf{p} 2}(\mathbf{m} / \mathbf{s})$ \\
\hline$A B-0$ & $6521 \pm 247$ & $6401.83 \pm 304$ \\
\hline$A B-2$ & $6093 \pm 329$ & $6088.04 \pm 28$ \\
\hline
\end{tabular}

Ambas rocas presentan valores elevados para las $V_{p}$ (especialmente en el caso de la roca $A B-0$ ). Estos resultados son similares al de otras rocas calizas como es la
Both rocks had high $V_{p}$ values (particularly rock $A B-0$ ). These findings are similar to the values for limestones such as Sierra Elvira (38), commonly used in 
caliza de Sierra Elvira (38), comúnmente utilizada como material de usos constructivos, y netamente superiores al de dolomías cretácicas como las de Ruedeña y de Torrelaguna (19).

\subsection{Durabilidad}

Ambas rocas presentan una pérdida en peso inferior al $0,5 \%$. La pérdida en peso en la roca $A B-0$ es de $0,36 \%$ mientras que en la roca $A B-2$ es de $0,13 \%$. El examen de visu de las probetas de ambas rocas a la conclusión del ensayo indica que no presentan ningún tipo de alteración.

La valoración de los cambios originados en el material pétreo tras los procesos de cristalización de sales se ha completado mediante el estudio de la modificación de sus propiedades hídricas (Tabla 7). El ensayo de cristalización de sales ha provocado un aumento en la porosidad abierta en $\mathrm{AB}-0$ del $14,13 \%$, en el contenido en humedad del $14,71 \%$ y en el coeficiente de absorción capilar del $51,78 \%$. En el caso de la roca AB-2, los aumentos en la porosidad abierta y en el contenido en humedad han sido respectivamente de $18,09 \%$ y $18,99 \%$, mientras que el coeficiente de absorción capilar muestra una reducción del 13,82\%. El aumento de la porosidad abierta indica un dominio de los procesos de cristalización de sales y génesis de nuevos poros y fisuras sobre los procesos de acumulación de sales, sin embargo la reducción en el coeficiente de absorción capilar apunta una disminución en la conectividad del sistema poroso de la roca como consecuencia de una obturación parcial de los poros por la acumulación de sales. construction, and substantially higher than the velocities reported for Cretaceous dolostones such as found in Ruedeña and Torrelaguna (19).

\subsection{Durability}

Both rocks exhibited weight loss of under $0.5 \%: 0.36 \%$ in $A B-0$ and $0.13 \%$ in $A B-2$. Further to the visual examination of both types of specimens after the trial, they remained unaltered.

The evaluation of the changes taking place in the stone after salt crystallization was supplemented with a study of variations in their hydric properties (Table 7). The salt crystallization test raised effective porosity in $A B-0$ by $14.13 \%$, moisture content by $14.71 \%$ and the capillary absorption coefficient by $51.78 \%$. In rock $A B-2$ effective porosity and moisture content rose respectively by 18.09 and $18.99 \%$, while the capillary absorption coefficient declined by $13.82 \%$. The increase in effective porosity denoted a predominance of salt crystallization and new pore and crack genesis over salt accumulation processes. By contrast, the decline in the capillary absorption coefficient indicated decreased pore system connectivity in the rock as a result of partial occlusion of the pores by the accumulating salts.

Tabla 7 / Table 7

Variaciones en las propiedades hídricas tras el ensayo de cristalización de sales. Variation in hydric properties after salt crystallization test.

\begin{tabular}{|c|c|c|c|c|c|c|c|c|c|}
\hline & \multicolumn{3}{|c|}{ Absorción agua / Water absorption (\%) } & \multicolumn{3}{|c|}{ Porosidad abierta / Effective porosity (\%) } & \multicolumn{3}{|c|}{$\begin{array}{c}\text { Absorción capilar / Capillary absorption } \\
\text { coefficient }\left(\mathrm{g}^{2} / \mathrm{m}^{2} \mathrm{~s}^{-0,5}\right)\end{array}$} \\
\hline & $\begin{array}{l}\text { Antes } I \\
\text { Before }\end{array}$ & $\begin{array}{c}\text { Después } I \\
\text { After }\end{array}$ & $\Delta \mathrm{W}(\%)$ & $\begin{array}{l}\text { Antes I } \\
\text { Before }\end{array}$ & $\begin{array}{l}\text { Después I } \\
\text { After }\end{array}$ & $\Delta P_{0}(\%)$ & $\begin{array}{l}\text { Antes I } \\
\text { Before }\end{array}$ & $\begin{array}{c}\text { Después I } \\
\text { After }\end{array}$ & C.A.C (\%) \\
\hline$A B-0$ & $0.24 \pm 0.04$ & $0.27 \pm 0.04$ & 14.71 & $0.65 \pm 0.19$ & $0.74 \pm 0.15$ & 14.13 & $1.31 \pm 1.04$ & $1.98 \pm 1.13$ & 51.78 \\
\hline$A B-2$ & $1.32 \pm 0.17$ & $1.57 \pm 0.04$ & 18.99 & $3.43 \pm 0.42$ & $4.05 \pm 0.21$ & 18.09 & $10.4 \pm 0.99$ & $8.92 \pm 0.44$ & -13.82 \\
\hline
\end{tabular}

\section{DISCUSIÓN}

La caliza de Abanto ( $A B-0)$ presenta, al igual que otras calizas mesozoicas como la de Sierra Elvira (38), una baja capacidad de absorción de agua, una porosidad abierta muy reducida, una elevada densidad y una elevada velocidad de propagación de ultrasonidos, características que le confieren una elevada calidad técnica para su utilización como material de uso constructivo.

La caliza cristalina de Abanto (AB-2) presenta una mayor absorción, saturación y coeficiente de absorción capilar que la caliza (AB-0), así como un proceso de secado más

\section{DISCUSSION}

Like other Mesozoic limestones such as Sierra Elvira (38), Abanto (AB-0) exhibits low water sorptivity, very small effective porosity, high density and a high ultrasound velocity, properties that translate into high suitability for use as a construction material.

Crystalline Abanto limestone (AB-2) has higher absorption, saturation and capillary absorption coefficients and dries more slowly than limestone $A B-0$. 
lento. Sin embargo, su tasa de secado junto con el bajo contenido crítico de agua le asegura una rápida transferencia hacia el exterior del agua absorbida y le hacen presentar un comportamiento favorable frente a los diferentes procesos de deterioro favorecidos por la circulación de fluidos.

Los resultados de los ensayos hídricos se correlacionan directamente con los tipos de procesos diagenéticos sufridos por las rocas. Así, las calizas y dolomías cristalinas han sufrido una diagénesis dominada por procesos de recristalización y cementación, que han provocado la eliminación de la porosidad primaria (inter e intrapartícula), generando una porosidad secundaria con una distribución de tamaños homogénea y que ha sido parcialmente sellada por el proceso de cementación tardía. Por otra parte, en las calizas (AB-0) la recristalización diagenética es mucho menos importante y está prácticamente circunscrita a la transformación micrita-microesparita en la matriz, por lo que el sistema poroso actual presenta rasgos tanto de la distribución original de poros como de las posteriores transformaciones diagenéticas.

La velocidad de propagación de ondas ultrasónicas depende en gran medida de las características texturales de la roca como son la composición mineralógica, la porosidad y la densidad de fracturación (39). Los valores elevados obtenidos para las $V_{p}$ indican una elevada calidad dinámica para estas rocas. Esta elevada velocidad de propagación de ondas ultrasónicas, y dada la probada relación entre velocidad de ultrasonidos y resistencia mecánica a compresión en rocas carbonatadas (40-42), sugiere una elevada resistencia mecánica de estos materiales.

El buen comportamiento de estas rocas frente al deterioro por sales es consecuencia de su baja porosidad, bajo grado de conectividad del sistema poroso, así como por el reducido tamaño medio de acceso de poro. Estas características determinan un sistema poroso tortuoso que dificulta la circulación de fluidos por su interior.

Los resultados obtenidos de pérdida en peso para el ensayo de cristalización de sales en la caliza cristalina (AB-2), indican una mayor durabilidad que en otras rocas carbonatadas cristalinas de su misma edad geológica como son las dolomías de Redueña y de Torrelaguna (19). La caliza cristalina de Abanto, y a diferencia de estas dolomías, presenta un mayor grado cementación lo que determina una menor porosidad abierta. Además, el buen comportamiento de la roca AB-0 indica que la durabilidad de este material no esta condicionada por las discontinuidades (estilolitos) que presenta.

La variación que tiene lugar tras la cristalización de sales en las propiedades físicas de los materiales pétreos permite identificar el grado o nivel de degradación alcanzado.
Nonetheless, its drying rate and low critical water content ensures speedy outward transfer of absorbed water and good performance when exposed to decay processes favoured by the circulation of fluids.

The results of the hydric tests are directly related to rock diagenesis. In these crystalline limestones and dolostones, diagenesis was governed by recrystallization and cementation processes that eliminated primary (inter- and intraparticle) porosity and generated secondary porosity in which the pore size distribution is homogeneous and the pores are partially sealed as a result of later cementation. By contrast, in $A B-0$ limestones, diagenetic crystallization is much less prevalent and practically limited to the transformation of micrite into microsparite in the matrix. Consequently, both the original size distribution and subsequent diagenetic transformations are visible in the present pore system.

Ultrasonic wave velocity depends largely on rock textural characteristics such as mineralogical composition, porosity and fracture density (39). The high $V_{p}$ values observed are indicative of the high dynamic quality of these rocks. Given the proven relationship between ultrasound velocity and compressive strength in carbonated rocks (40-42), these values also suggest that these materials have high mechanical strength.

Their good performance when exposed to salt-induced decay is a result of their low porosity, scant pore system connectivity and small mean pore throat size. The intricacy of the pore system resulting from these characteristics hinders fluid circulation inside the stone.

The weight loss findings in the salt crystallization test for the crystalline limestone $(A B-2)$ denote higher durability than in other crystalline carbonated rocks of the same geological age, such as Redueña and Torrelaguna dolostones (19). Abanto crystalline limestone exhibits greater cementation than these dolostones, which translates into lower effective porosity. Furthermore, the good performance of rock $A B-0$ indicates that its durability is not conditioned by its discontinuities (stylolites).

The post-salt crystallization variations observed in the physical properties of these materials provides a measure of the degree of decay induced. Despite the 
A pesar de que la pérdida en peso en ambas rocas es muy baja, el incremento de la porosidad tras el ensayo de cristalización sales (18,09\% en $A B-2$ y $14,14 \%$ en $A B-$ 0 ) indica un cierto grado de deterioro en el material.

\section{CONCLUSIONES}

Las rocas explotadas en Abanto corresponden a dos tipos petrológicos muy distintos en cuanto a su mineralogía y textura. La caliza cristalina, engloba niveles carbonatados que han sufrido una destrucción de su textura original de depósito como consecuencia de procesos de dolomitización y dedolomitización. El mayor volumen canterable corresponde a dolomías cristalinas, entre las cuales aparecen niveles de menor espesor de calizas cristalinas, pero a pesar de esta diferencia composicional son texturalmente muy similares entre sí. Por otra parte, la caliza (AB-0) corresponde a una roca calcárea de tipo wackestone-biopelmicrita que ha sufrido una diagénesis mucho menos destructiva, y donde el estudio petrográfico ha permitido describir su textura de depósito.

La caracterización del sistema poroso para la caliza (AB-0) indica un sistema poroso tortuoso, heterogéneo, compuesto por accesos de poros de pequeño tamaño (más del $89 \%$ de los radios de accesos de poro son inferiores a $0,1 \mu \mathrm{m}$ ) y con una baja conectividad, mientras que la caracterización del sistema poroso para la caliza cristalina (AB-2) indica un sistema poroso mejor comunicado, pero compuesto también por accesos de poros de pequeño tamaño (fundamentalmente inferiores a 0,2 $\mu \mathrm{m}$ ).

Tanto la caliza cristalina (AB-2) como la caliza (AB-0), a pesar de las numerosas discontinuidades que posee, presentan una buena respuesta frente al deterioro por cristalización de sales, con una pérdida en peso inferior al $0,5 \%$ en ambas rocas. Además, estos materiales presentan una elevada durabilidad frente al deterioro por contaminación atmosférica y agentes como el agua, tal y como se puede observar por el buen estado de conservación que presentan las obras que a lo largo del tiempo se han construido con estos materiales.

Esta caracterización pone de manifiesto que tanto las calizas con textura deposicional como las calizas y dolomías cristalinas caracterizadas por presentar una porosidad abierta baja y porcentajes elevados de microporosidad con tamaño de radios de acceso de poro preferentemente inferiores a $0,2 \mu \mathrm{m}$, serán rocas muy poco alteradas por los procesos de cristalización de sales.

Las características petrográficas y texturales, la baja porosidad, el bajo coeficiente de absorción capilar, la elevada velocidad de propagación de ondas ultrasónicas y su small weight loss observed in both stones, the increase in porosity after the salt crystallization trial $(18.09 \%$ in $A B-2$ and $14.14 \%$ in $A B-0$ ) denotes a certain degree of material decay.

\section{CONCLUSIONS}

The rocks quarried at Abanto exhibit two very different petrologies in terms of mineralogy and texture. Crystalline limestone includes carbonated layers whose original depositional texture was destroyed by dolomitization and de-dolomitization. Most of the quarriable volume is made of up of crystalline dolostone, however, interrupted by thinner layers of this crystalline limestone. Despite this compositional difference, the two varieties are texturally very similar. In addition, since the limestone $(A B-0)$ is a wackestone-biopelmicrite type rock that underwent much less destructive diagenesis, the petrographic study revealed its depositional structure.

The "Pinta Morada" limestone (AB-0) pore system is intricate, heterogeneous, characterized by small size pores (over $89 \%$ with radii under $0.1 \mu \mathrm{m}$ ) and low connectivity, while the crystalline limestone $(A B-2)$ has a more highly connected pore system, likewise consisting of small pores (essentially under $0.2 \mu \mathrm{m}$ ).

Despite their numerous discontinuities, both the crystalline limestone $(A B-2)$ and the limestone $(A B-0)$ perform well when exposed to salt crystallizationinduced decay, with a weight loss of under $0.5 \%$. These materials are also highly resistant to air pollution and agents such as water, as can be deduced from the good condition of the monuments and buildings constructed with this type of stone.

These properties indicate that both limestone with a depositional texture and crystalline limestone and dolostone characterized by low effective porosity and high percentages of micropores with throat radii mostly under 0,2 $\mathrm{\mu m}$ are rocks scantly altered by salt crystallization processes.

The petrographic and textural characteristics, low porosity, low capillary absorption coefficient, high ultrasonic wave velocity and good performance in salt 
Caracterización del sistema poroso y de su influencia en el deterioro por cristalización de sales en calizas y dolomías explotadas en Abanto (Zaragoza, España) Characterization of pore system and their influence on decay rates caused by salt weathering on limestones and dolostones quarried in Abanto (Zaragoza, Spain)

buen comportamiento durante el ensayo de cristalización de sales indican una elevada calidad técnica de estos materiales para su utilización como elementos de uso constructivo.

\section{AGRADECIMIENTOS}

A la Consejería de Industria del Gobierno de Aragón por la concesión de una beca predoctoral al primero de los autores (O. B.) Ref. B044, 2004, gracias a la cual se ha realizado parte de este trabajo, y a la empresa Canteras Abanto, S.L. por suministrarnos el material. crystallization tests stand as proof of the suitability of these materials for use in construction.

\section{BIBLIOGRAFÍA / BIBLIOGRAPHY}

(1) Montoto, M.: "Petrophysics: The petrographic interpretation of the physical properties of rocks". Proceedings of the 5th Congress of the International Society for Rock Mechanics (1983), pp. 93-98.

(2) Alonso, F. J.: "Caracterización petrofísica y alterabilidad de calizas y dolomías". Tesis doctoral, Departamento de Petrología, Universidad de Oviedo (1986), p. 209.

(3) Alonso, F. J.; Esbert, R. M.; Ordaz, J.: "Caracterización del sistema poroso de calizas y dolomías". Boletín geológico y minero (1987),

T. XCVIII-II, pp. 226-237.

(4) Esbert, R. M.; Ordaz, J.: "Alteración y alterabilidad de las piedras de construcción: criterios petrofísicos y ensayos de laboratorio", I congreso de patología en la edificación, C.O.A.C., Barcelona (1985), pp. 15.

(5) Vos, B. H.: "Hygric methods for the determination of the behaviour of stones". Proceeding of the International Symposium on deterioration and Protection of Stone Monuments, París (1978), 3.8, pp. 19.

(6) Everett, D. H. "The thermodynamics of frost damage to porous solids". Transactions of the Faraday Society, vol. 465 (57, 9) (1961), pp. 1441-1451.

(7) Litvan, G. G.: "Frost action in porous system". Séminarie Alteration et Durabilité des Betons et des Pierres, vol. 1 (1981), pp. 95108.

(8) Goudie, A. S.; Viles, H. A.: Salt weathering hazard, Wiley (1997), p. 256.

(9) Fort, R.; Bernabéu, A.; García del Cura, M. A.; López de Azcona, M. C.; Ordóñez, S.; Mingarro, F.: "Novelda Stone: a stone widely used within the spanish architectural heritage". Mater. Construcc., no 266 (2002), pp. 19-32.

(10) Correns, C. W.: "Growth and dissolution of crystals under linear pressure". Discuss Faraday Society, vol. 5 (1949), pp. $267-271$. doi:10.1039/df9490500267

(11) Weyl, P. K.: "Pressure solution and the force of crystallisation. A phenomenological theory". Journal of Geophysical Research, vol. 64 (1959), pp. 2.001-2.025. doi:10.1029/JZ064i011p02001

(12) Evans, I. S.: "Salt crystallization and rock weathering". A review. Revue de Géomorphologie Dynamique, vol. 19 (1970), pp. $155-177$.

(13) Franzini, M.: "Stones in monuments: natural and anthropogenic deterioration of marble artefacts". European Journal of Mineralogy, vol. 7 (1995), pp. 735-743.

(14) Price, C. A.: "Stone Conservation: An Overview of Current research". Getty Institute, Santa Mónica (1996), p. 88.

(15) Benavente, D.; García del Cura, M. A.; Fort, R.; Ordoñez, S.: "Thermodynamic modelling of changes induced by salt pressure crystallisation in porous media of stone". Journal of Crystal Growth, vol. 204 (1999), pp. 168-178. doi:10.1016/S0022-0248(99)00163-3

(16) Rodríguez-Navarro, C.; Dohene, E.: "Salt weathering: influence of evaporation rate, supersaturation and crystallisation pattern". Earth surface Processes and Landforms, vol. 24 (1999), pp. 191-209. doi:10.1002/(SICI)1096-9837(199903)24:3<191::AIDESP942>3.0.CO;2-G

(17) Scherer, G. W.: "Crystallisation in pores". Cem. Concr. Res., vol. 29 (1999), pp. 1347-1358. doi:10.1016/S0008-8846(99)00002-2

(18) Flatt, R. J.: "Salt damage in porous materials: how high supersaturations are generated". Journal of Crystal Growth, vol. 242 (2002), pp. 435-454. doi:10.1016/S0022-0248(02)01429-X

(19) Fort, R.; Fernández-Revuelta, B.; Varas, M. J.; Taborda-Duarte, M.: "Effect of anisotropy on Madrid-region Cretaceous dolostone durability in salt crystallization processes". Mater. Construcc., vol. 58, no 289-290 (2008), pp. 161-177.

(20) Alonso, F. J.; Vázquez, P.; Esbert, R. M.; Ordaz, J.: "Ornamental granite durability: evaluation of damage caused by salt crystallization test". Mater. Construcc., vol. 58, no 289-290 (2008), pp. 191-201.

(21) Villena, J.; Canerot, J.: "El Cretácico de la Cordillera Ibérica (Sector Central)". Grupo Español del Mesozoico. P.I.G.C. Mid Cretaceous Events. Departamento de Estratigrafía, Facultad de Ciencias, Universidad de Zaragoza (1981). 
(22) Vera, J. A.: "Cordilleras Ibérica y Costero-Catalana". Geología de España, Instituto Geológico y Minero de España, Sociedad Geológica Española (2004), pp. 467-470.

(23) Del Olmo, P.; Portero, J. M.: Hoja Geológica no 464 (Used). Mapa Geológico de España, escala 1:50000, IGME, Madrid (1983), p. 74.

(24) Norma UNE-EN 12407 (2001). "Métodos de ensayo para piedra natural. Estudio petrográfico", p. 11.

(25) Dean, W. E.: "Determination of carbonate and organic matter in calcareous sediments and sedimentary rocks by loss on ignition: comparison with other methods". Journal of Sedimentary Petrology, no 44 (1974), pp. 242-248.

(26) Norma UNE-EN 1936 (1999). "Métodos de ensayo parta piedra natural. Determinación de la densidad real y aparente y de la porosidad abierta y total", p. 13.

(27) Norma UNE-EN 13755 (2002). "Métodos de ensayo para piedra natural. Determinación de la absorción de agua a presión atmosférica", p.10.

(28) Norma UNE-EN 1925:1999. "Métodos de ensayo para piedra natural. Determinación del coeficiente de absorción de agua por capilaridad", p. 13.

(29) Norma UNE-EN 12370:1999. "Métodos de ensayo para piedra natural. Determinación de la resistencia a la cristalización de las sales", p. 10.

(30) Munsell: Munsell soil color charts. Munsell products. Baltimore (1976), Maryland.

(31) Friedman, G. M.: "Terminology of crystallization textures and fabrics in sedimentary rocks". Journal of Sedimentary Research, vol. 35; no. 3 (1966), pp. 643-655.

(32) Sibley, D. F.; Gregg, J. M.: "Classification of dolomite rock textures". Journal of Sedimentary Petrology, vol. 57 (6) (1987), pp. 967975.

(33) Folk, R. L.: "Spectral subdivision of limestones types". W. E. Ham. Ed, Classification of carbonate rocks. The American Association of Petroleum Geologists, no 1 (1962), pp. 62-84.

(34) Dunham, R. J.: "Classification of carbonate rocks according to depositional texture", Ham, W. E. (ed.), Classification of carbonate rocks: American Association of Petroleum Geologists Memoir (1962), pp. 108-121.

(35) Riganti, V.; Perotti, A.; Fiumara, A.; Veniale, F.; Zezza, U.: "Applicazione di tecniche strumentali al controlo del degrado delle pietre nei moniment: il caso Della Basílica de S. Michele in Pavia". Museo Civico Storia Naturalle, Milán, vol. 122 (1981), pp. 109-138.

(36) Pellegrin, F. M.: "La porosimetría au mercure apliqué à l’étude géotechnique des sols et des roches". Bulletin des Liason des Laboratoires des Ponts et Chaussées, vol. 106 (1980), pp. 105-116.

(37) García del Cura, M. A.; Benavente, D.; Bernabéu, A.; Fort R.; La Iglesia, A.; Ordoñez, S.: "Microcrystalline limestone used as building stone: The Case of Gris Pulpis Stone". Mater. Construcc. vol. 55, no 277 (2005), pp. 5-23.

(38) Sebastián Pardo, E.; Cultrone, G.; Garibaldi, V.; Rodríguez Navarro, C.; De la Torre, M. J.; Valverde, I.: "The Sierra Elvira limestone: petrophysical features of a widespread Andalusian decorative material". Mater. Construcc., vol. 58, no $289-290$ (2008), pp. 51-63.

(39) Mamillan, M.: "Connaissances actuelles pour mesurer le degré d'altération des pierres et l'efficacité des methodes de traitement". 1st. International Symposium on the deterioration of building stones, La Rochelle (1972), pp. 47-56.

(40) Guerrero M. A.; Vázquez M. A.; Galán, E.; Zezza, F.: "The physical-mechanical properties and ultrasonic data as criteria for evaluation of calcareous stone decay". La Conservazione dei Monumenti nel bacino del Mediterraneo. 1st International Symposium Bari (1989), pp. 309-312.

(41) Bouineau, A.: "L'intérêt des essais non destructifs utilisés pour l'étude de la restauration des monuments et des sculptures". Alteration et protection des monuments en pierres, RILEM, París (1978), pp. 1-29.

(42) Krtolica, B.; Crnkovié, B.: "Ultrasonic testing of stone quality". 3rd International Congress on the Deterioration and Preservation of Stones, Venezia (1979), pp. 219-225. 